\title{
Shared pathways to infectious disease susceptibility?
}

\author{
Chiea C Khor ${ }^{1,2}$ and Martin L Hibberd ${ }^{* 1,2}$
}

\begin{abstract}
The recent advent of genomic approaches for association testing is starting to enable a more comprehensive understanding of the role of human immune response in determining infectious disease outcomes. Progressing from traditional linkage approaches using microsatellite markers to highresolution genome-wide association scans, these new approaches are leading to the robust discovery of a large number of disease susceptibility genes and the beginnings of an appreciation of their connections. In this commentary, we discuss how this technology development has led to increasingly complex and common infectious diseases being unraveled, and how this is starting to dissect pathogen-specific human responses. Intriguingly, these still preliminary findings suggest that pathogen innate detection mechanisms may not be as shared among diseases as immune response mechanisms.
\end{abstract}

\section{Introduction}

Many severe diseases resulting from infections, such as meningitis, dengue, or leprosy, are relatively rare within the human population when compared with the often ubiquitous nature of the causative infectious agent in specific world regions. While antibody responses to these organisms can be measured in large percentages of these populations, disease leading to hospitalization affects a small minority. This has led to the realization that the type of host response made to an infectious encounter may play a large role in determining the outcome. Understanding how most people successfully contain these infectious challenges may lead to the development of novel therapeutics for those individuals at risk of severe disease.

\footnotetext{
*Correspondence: hibberdml@gis.a-star.edu.sg
}

'Infectious Diseases, Genome Institute of Singapore, 60 Biopolis Street, \#02-01 Genome, 138672 Singapore. '2Department of Epidemiology and Public Health, National University of Singapore, 16 Medical Drive (MD 3), 11759 Singapore
This application of human genetics has proven insightful in those rare humans who are broadly susceptible to infections, where Mendelian genetic linkage approaches have revealed highly penetrant mutations that cause disease. With the advent of genome-wide association study (GWAS) technology, the field has been looking to see if the lessons learnt can be carried over to more common infectious diseases.

\section{Severe combined immune deficiency and partial immune deficiency}

The first studies of immune response defects and infectious disease outcomes strongly suggested that infectious diseases would have shared pathways to disease. Severe combined immune deficiency (SCID) - a genetic disorder that affects the adaptive immune system - demonstrates the importance of the immune system in protection against infection, as patients with SCID quickly succumb to life-threatening sepsis from a very wide range of infectious agents. The gene responsible for the majority of SCID cases, CD132 (the common $\gamma$-chain), was identified using the traditional linkage approach [1-3]. Because the common $\gamma$-chain is shared by many cytokine receptors (receptors for IL-2, IL-4, IL-7, IL-9, IL-15, and IL-21), mutations that result in a non-functional common $\gamma$-chain cause widespread defects in IL signaling and failure of B and T cells to develop and mature. This is a rather profound example, and knowledge of the responsible gene has opened avenues for therapeutic intervention in cases of X-linked SCID, where gene transfer of the normal CD132 appears to be a promising, even curative, treatment modality $[4,5]$. Similar observations and clinical conclusions have been made with another form of SCID caused by defects in the variable, diversity, joining recombination process [6].

Partial immune deficiency, referring to the inactivation of a single immune pathway due to genetic mutations in one or more members of the network, was initially suspected to act in a similar way to the SCID mutations, with patients having a predisposition to a wide variety of infections. As these mutations are highly penetrant, traditional genetic linkage studies have been able to isolate the responsible genes and pathways for some of 
these conditions, many of which have severe or even fatal clinical presentations. Notable examples include the IFN- $\gamma$ receptor (IFNGR1) in cases of severe mycobacterial infections [7], the lysosomal trafficking regulator (LYST) for Chediak-Higashi syndrome [8], and Bruton's tyrosine kinase for X-linked agammaglobulinemia $[9,10]$.

While the immune system has multiple pathways, each is thought to be active against a wide range of microorganisms. Thus, it is perhaps surprising that the spectrum of infection susceptibility for these three genes appears to be fairly constrained. For example, IFNGR1 mutations mainly predispose to mycobacterial infections, and LYST and Bruton's tyrosine kinase mutations mainly predispose to predominantly pyogenic bacterial infections (for example, Streptococcus pyogenes, pneumococcus, and Haemophilus influenzae). This surprising finding echoes another example: that of complement deficiency and its observed confinement to increased susceptibility towards encapsulated bacteria, particularly Neisseria spp., despite consistent documentation on the importance of the complement pathway in common blood pathogen clearance $[11,12]$.

\section{Subtle changes to immune genes as a result of genetic polymorphism}

In the last 5 years, advances in genomic research have enabled the use of the GWAS design, permitting the robust identification of host susceptibility genes for infectious pathogens in increased detail. Although the advent of GWAS in infectious diseases has been slow compared with GWAS in many other complex disease phenotypes $[13,14]$, this approach has nonetheless allowed unprecedented identification (or confirmation) of genes associated with susceptibility to the infectious diseases studied so far [15-18].

Infectious disease genes identified via the GWAS approach have thus far been relatively 'pathogen specific', with cross-pathogen sharing being the exception rather than the rule.

The greatest surprise has related to observations within the human leukocyte antigen (HLA) locus, where broadbased sharing between pathogen groups could be expected, given the central role played by HLA in immune recognition of pathogens and the initiation of immune responses. However, recent GWAS have found that while different HLA alleles appear to be shared between various auto-immune phenotypes (such as psoriasis [19], vitiligo [20], or systemic lupus erythematosus [21]), there appears to be little evidence of substantial susceptibility sharing for HLA between different infectious diseases. This disparity is striking even among supposedly 'similar' pathogen groups: a very strong contribution of the HLA locus has been observed for leprosy (Mycobacterium leprae) [15,22], but not for tuberculosis (Mycobacterium tuberculosis) susceptibility [23,24], highlighting the vast complexity of the immune response to diverse pathogens. This complexity is further shown in two genetic studies of vaccine response: while the HLA is crucial for success (or otherwise) for hepatitis B virus vaccination [25], it is not the case for $H$. influenzae type b vaccination [26].

Although findings thus far have suggested that the main pathways underlying susceptibility to pathogenic infection are pathogen specific, it is nonetheless relevant to understand similarities in the infection and invasion process for the very diverse pathogens that the human body encounters daily. For example, knowledge gleaned from the rare primary immune deficiencies has shown that defects in extremely central components of the immune system result in broad, general susceptibility to multiple infectious diseases. Elucidation of the responsible genes and pathways often yields considerable insight into disease mechanisms and pathogenesis, and can inform medical treatment (a good example being the case of X-linked agammaglobulinemia where common antibiotic treatments do not suffice, and immunoglobulin replacement is necessary). If some of these therapeutic findings could be extended to the commoner forms of infection that clinicians encounter on a daily basis, this could have an immediate public health impact.

Genomic approaches have played a supporting role in the identification of potential therapeutic targets. One of the virulent capabilities of Neisseria meningitidis is its ability to recruit human factor $\mathrm{H}$ (encoded by $\mathrm{CFH}$ ) via molecular mimicry [27], thus avoiding complementmediated killing of the bacterium. A recently completed GWAS on host susceptibility to meningococcal disease has shown that genetic polymorphisms within $\mathrm{CFH}$ as well as $C F H$-related genes are very strongly associated with susceptibility to meningococcal disease [18]. As the bacterial factor $\mathrm{H}$-binding protein is now a strong meningococcal vaccine candidate [28], it is clear that genomic approaches can be used independently to discover or to confirm therapeutic targets identified by functional approaches.

Leprosy, tuberculosis, Crohn's disease, and ulcerative colitis have also been the subjects of recent investigations. Indeed, genomic approaches have underlined the importance of the nucleotide-binding oligomerization domain containing (NOD)2 signaling cascade in inflammatory and infectious diseases. Different members of the pathway (NOD2, TNFSF15, and RIPK2) have been strongly implicated $\left(P<10^{-10}\right)$ in susceptibility to leprosy [15,29], as well as Crohn's disease, which is an inflammatory bowel disease with substantial links to infectious agents $[30,31]$. However, observations by us and others [24] do not implicate NOD2 pathway members as strongly in tuberculosis susceptibility. The same has been observed for CARD9 (a member of the extended NOD family of 
genes), which has been strongly associated with ulcerative colitis susceptibility [32] and functionally implicated in tuberculosis [33], but not with leprosy [15].

Another gene observed to be a strong $\left(P<10^{-10}\right)$ susceptibility factor for leprosy is TNFSF15 [15]. The exact same SNP (rs6478108) has also been found to be strongly associated $\left(P<10^{-10}\right)$ with Crohn's disease [34]. However, the minor allele has been found to be associated with increased risk of leprosy, but with decreased risk of Crohn's disease. This suggests that differential regulation of the immune response appears to be critical to reach a balance between protection from invading pathogens and susceptibility to inflammatory disorders, thus highlighting TNFSF15 as a potential therapeutic target in manipulation of the strength of the immune response.

Indeed, the disparity in susceptibility genes for Crohn's disease and ulcerative colitis (different members of the pathogen-sensing CARD family are involved: NOD2 for Crohn's, and CARD9 for ulcerative colitis) is likely to reflect different sites of pathology, different bacterial spectra, and therefore different mechanisms for microbial recognition. Strikingly, there is evidence suggesting that the downstream, cytokine-mediated pathogenesis pathways (for example, those involving IL-23) could be common across both diseases [32].

\section{Missing 'shared susceptibility'?}

The majority of evidence collected so far from genomic approaches appears to suggest that, barring specific exceptions, common host susceptibility to different invading pathogens appears to be controlled by discrete genes and pathways. As genomic approaches are still limited in resolution, there is a possibility that truly shared mechanisms governing susceptibility across multiple pathogen groups have yet to be found. This seems to be likely in view of the finite number of pathogenrecognizing receptors available at the first lines of defence, coupled with their convergent, downstream signaling pathways. An example for 'shared susceptibility' would be TIRAP, which encodes a common adaptor for two major pathogen-sensing receptors (TLR2 and TLR4); an inactivating mutation (S180L) within TIRAP appears to associate with susceptibility to invasive pneumococcus and $H$. influenzae, as well as Trypanosoma cruzi infections $[26,35,36]$, with a yet unconfirmed association with tuberculosis [37,38].

Considering the evidence now available, there is reason to believe that host susceptibility to infection could be specific and 'mechanism dependent' in terms of pathogen recognition and the site of infection, with shared common signaling pathways playing an important role downstream of pathogen contact points.

A further benefit in the large-scale deployment of hypothesis-free genomic approaches is that they could help in establishing the etiology of certain autoimmune diseases where infectious diseases have long been suspected - but not confirmed - to be a predisposing factor. For example, in the case of type 1 diabetes, GWAS have implicated an extraordinary number of immunerelated genes, some of which overlap with infection pathways, thus lending credence to the above hypothesis.

Genomic approaches have resulted in improved treatment strategies for patients with severe and partial immune deficiencies by identifying the deficient protein component(s), but for many of the common infections, due to their complex nature, genomic approaches have not yet been as fruitful in informing medical treatment. Emerging antibiotic resistance is putting additional pressure on research efforts in host and pathogen genomics for further improvement of therapeutic strategy beyond antimicrobial treatment, but there is hope that this research will lead to novel human protein-based therapies.

\begin{abstract}
Abbreviations
GWAS, genome-wide association studies; HLA, human leukocyte antigen; IL, interleukin; NOD2, nucleotide-binding oligomerization domain containing; SCID, severe combined immune deficiency; SNP, single nucleotide polymorphism.
\end{abstract}

\section{Competing interests}

The authors declare that they have no competing interests.

\section{Authors' contributions}

Both authors have contributed to the conceptualization and preparation of this manuscript and approved the final version.

\section{Acknowledgements}

CCK and MLH are supported by the Agency for Science, Technology and Research (A-STAR), Singapore

\section{Published: 12 August 2010}

\section{References}

1. Puck JM, Deschenes SM, Porter JC, Dutra AS, Brown CJ, Willard HF, Henthorn PS: The interleukin-2 receptor gamma chain maps to Xq13.1 and is mutated in X-linked severe combined immunodeficiency, SCIDX1. Hum Mol Genet 1993, 2:1099-1104.

2. Puck JM, Conley ME, Bailey LC: Refinement of linkage of human severe combined immunodeficiency (SCIDX1) to polymorphic markers in Xq13. Am J Hum Genet 1993, 53:176-184.

3. Puck JM, Nussbaum RL, Smead DL, Conley ME: X-linked severe combined immunodeficiency: localization within the region Xq13.1-q21.1 by linkage and deletion analysis. Am J Hum Genet 1989, 44:724-730.

4. Cavazzana-Calvo M, Hacein-Bey S, de Saint Basile G, Gross F, Yvon E, Nusbaum P, Selz F, Hue C, Certain S, Casanova JL, Bousso P, Deist FL, Fischer A: Gene therapy of human severe combined immunodeficiency (SCID)-X1 disease. Science 2000, 288:669-672.

5. Cavazzana-Calvo M, Fischer A: Efficacy of gene therapy for SCID is being confirmed. Lancet 2004, 364:2155-2156.

6. Niehues T, Perez-Becker R, Schuetz C: More than just SCID - the phenotypic range of combined immunodeficiencies associated with mutations in the recombinase activating genes (RAG) 1 and 2. Clin Immunol 2010, 135:183-192.

7. Newport MJ, Huxley CM, Huston S, Hawrylowicz CM, Oostra BA, Williamson R, Levin M: A mutation in the interferon-gamma-receptor gene and susceptibility to mycobacterial infection. NEng/ J Med 1996, 335:1941-1949.

8. Barrat FJ, Auloge L, Pastural E, Lagelouse RD, Vilmer E, Cant AJ, Weissenbach J, Le Paslier D, Fischer A, de Saint Basile G: Genetic and physical mapping of the Chediak-Higashi syndrome on chromosome 1q42-43. Am J Hum Genet 1996, 59:625-632. 
9. Mensink EJ, Thompson A, Schot JD, van de Greef WM, Sandkuyl LA, Schuurman RK: Mapping of a gene for X-linked agammaglobulinemia and evidence for genetic heterogeneity. Hum Genet 1986, 73:327-332.

10. Kwan SP, Kunkel L, Bruns G, Wedgwood RJ, Latt S, Rosen FS: Mapping of the X-linked agammaglobulinemia locus by use of restriction fragmentlength polymorphism. J Clin Invest 1986, 77:649-652.

11. Mathew S, Overturf GD: Complement and properidin deficiencies in meningococcal disease. Pediatr Infect Dis J 2006, 25:255-256

12. Sjoholm AG, Jonsson G, Braconier JH, Sturfelt G, Truedsson L: Complement deficiency and disease: an update. Mol Immunol 2006, 43:78-85.

13. Sladek R, Rocheleau G, Rung J, Dina C, Shen L, Serre D, Boutin P, Vincent D, Belisle A, Hadjadj S, Balkau B, Heude B, Charpentier G, Hudson TJ, Montpetit A, Pshezhetsky AV, Prentki M, Posner BI, Balding DJ, Meyre D, Polychronakos C, Froguel P: A genome-wide association study identifies novel risk loci for type 2 diabetes. Nature 2007, 445:881-885.

14. Davila S, Hibberd ML: Genome-wide association studies are coming for human infectious diseases. Genome Med 2009, 1:19.

15. Zhang FR, Huang W, Chen SM, Sun LD, Liu H, Li Y, Cui Y, Yan XX, Yang HT, Yang RD, Chu TS, Zhang C, Zhang L, Han JW, Yu GQ, Quan C, Yu YX, Zhang Z, Shi BQ Zhang LH, Cheng H, Wang CY, Lin Y, Zheng HF, Fu XA, Zuo XB, Wang Q, Long $\mathrm{H}$, Sun YP, Cheng YL, et al:: Genomewide association study of leprosy. N Engl J Med 2009, 361:2609-2618.

16. Jallow M, Teo YY, Small KS, Rockett KA, Deloukas P, Clark TG, Kivinen K, Bojang KA, Conway DJ, Pinder M, Sirugo G, Sisay-Joof F, Usen S, Auburn S, Bumpstead SJ, Campino S, Coffey A, Dunham A, Fry AE, Green A, Gwilliam R, Hunt SE, Inouye M, Jeffreys AE, Mendy A, Palotie A, Potter S, Ragoussis J, Rogers J, Rowlands K, et al: Genome-wide and fine-resolution association analysis of malaria in West Africa. Nat Genet 2009, 41:657-665.

17. Fellay J, Shianna KV, Ge D, Colombo S, Ledergerber B, Weale M, Zhang K Gumbs C, Castagna A, Cossarizza A, Cozzi-Lepri A, De Luca A, Easterbrook P, Francioli P, Mallal S, Martinez-Picado J, Miro JM, Obel N, Smith JP, Wyniger J, Descombes P, Antonarakis SE, Letvin NL, McMichael AJ, Haynes BF, Telenti A, Goldstein DB: A whole-genome association study of major determinants for host control of HIV-1. Science 2007, 317:944-947.

18. Davila S, Wright V, Khor CC, Sim KS, Binder A, Breunis WB, Inwald D, Nadel S, Betts H, Carrol ED, de Groot R, Hermans PW, Hazelzet J, Emonts M, Lim CC, Kuijpers TW, Martinon-Torres F, Salas A, Zenz W, Levin M, Hibberd ML, on behalf of the International Meningococcal Genetics Consortium: Genomewide association study identifies variants in the $\mathrm{CFH}$ region associated with host susceptibility to meningococcal disease. Nat Genet 2010, in press.

19. Zhang XJ, Huang W, Yang S, Sun LD, Zhang FY, Zhu QX, Zhang FR, Zhang C, Du WH, Pu XM, Li H, Xiao FL, Wang ZX, Cui Y, Hao F, Zheng J, Yang XQ, Cheng $H$, He CD, Liu XM, Xu LM, Zheng HF, Zhang SM, Zhang JZ, Wang HY, Cheng YL, Ji BH, Fang QY, Li YZ, Zhou FS, et al.: Psoriasis genome-wide association study identifies susceptibility variants within LCE gene cluster at 1q21. Nat Genet 2009, 41:205-210

20. Jin Y, Birlea SA, Fain PR, Gowan K, Riccardi SL, Holland PJ, Mailloux CM, Sufit AJ, Hutton SM, Amadi-Myers A, Bennett DC, Wallace MR, McCormackWT, Kemp EH, Gawkrodger DJ, Weetman AP, Picardo M, Leone G, Taïeb A, Jouary T, Ezzedine K, van Geel N, Lambert J, Overbeck A, Spritz RA: Variant of TYR and autoimmunity susceptibility loci in generalized vitiligo. N Engl J Med 2010, 362:1686-1697.

21. International Consortium for Systemic Lupus Erythematosus Genetics (SLEGEN), Harley JB, Alarcón-Riquelme ME, Criswell LA, Jacob CO, Kimberly RP, Moser KL, Tsao BP, Vyse TJ, Langefeld CD, Nath SK, Guthridge JM, Cobb BL, Mirel DB, Marion MC, Williams AH, Divers J, Wang W, Frank SG, Namjou B, Gabriel SB, Lee AT, Gregersen PK, Behrens TW, Taylor KE, Fernando M, Zidovetzki R, Gaffney PM, Edberg JC, Rioux JD, et al: Genome-wide association scan in women with systemic lupus erythematosus identifies susceptibility variants in ITGAM, PXK, KIAA1542 and other loci. Nat Genet 2008, 40:204-210.

22. Wong SH, Gochhait S, Malhotra D, Pettersson FH, Teo YY, Khor CC, Rautanen A, Chapman SJ, Mills TC, Srivastava A, Rudko A, Freidin MB, Puzyrev VP, Ali S, Aggarwal S, Chopra R, Reddy BS, Garg VK, RoyS, Meisner S, Hazra SK, Saha B, Floyd S, Keating BJ, Kim C, Fairfax B, Knight JC, Hill PC, Adegbola R, Hakonarson $\mathrm{H}$, et al: Leprosy and the adaptation of human Toll-like receptor 1. PLoS Pathog, in press.

23. Bellamy R, Beyers N, McAdam KP, Ruwende C, Gie R, Samaai P, Bester D, Meyer M, Corrah T, Collin M, Camidge DR, Wilkinson D, Hoal-Van Helden E, Whittle $H C$, Amos W, van Helden P, Hill AV: Genetic susceptibility to tuberculosis in Africans: a genome-wide scan. Proc Natl Acad Sci U S A 2000, 97:8005-8009.

24. Thye T, Vannberg FO, Wong SH, Owusu-Dabo E, Osei I, Gyapong J, Sirugo G, Sisay-Joof F, Enimil A, Chinbuah MA, Floyd S, Warndorff DK, Sichali L, Malema
S, Crampin AC, Ngwira B, Teo YY, Small K, Rockett K, Kwiatkowski D, Fine PE, Hill PC, Newport M, Lienhardt C, Adegbola RA, Corrah T, Ziegler A, African TB Genetics Consortium, The Wellcome Trust Case Control Consortium, Morris AP, et al.: Genome-wide association analyses identifies a susceptibility locus for tuberculosis on chromosome 18q11.2. Nat Genet 2010, in press

25. Davila S, Froeling FE, Tan A, Bonnard C, Boland GJ, Snippe H, Hibberd ML, Seielstad M: New genetic associations detected in a host response study to hepatitis B vaccine. Genes Immun 2010, 11:232-238.

26. Ladhani SN, Davila S, Hibberd ML, Heath PT, Ramsay ME, Slack MP, Pollard AJ, Booy R: Single nucleotide polymorphisms in Mal/TIRAP and interleukin-10 genes are associated with susceptibility to invasive Haemophilus influenzae serotype b (Hib) infection in immunised children. Clin Infect Dis, in press.

27. Schneider MC, Prosser BE, Caesar JJ, Kugelberg E, Li S, Zhang Q, Quoraishi S, Lovett JE, Deane JE, Sim RB, Roversi P, Johnson S, Tang CM, Lea SM: Neisseria meningitidis recruits factor $\mathrm{H}$ using protein mimicry of host carbohydrates. Nature 2009, 458:890-893.

28. Pizza M, Donnelly J, Rappuoli R: Factor H-binding protein, a unique meningococcal vaccine antigen. Vaccine 2008, 26 Suppl 8:146-48.

29. Schurr E, Gros P: A common genetic fingerprint in leprosy and Crohn's disease? N Engl J Med 2009, 361:2666-2668.

30. Hugot JP, Chamaillard M, Zouali H, Lesage S, Cezard JP, Belaiche J, Almer S, Tysk C, O'Morain CA, Gassull M, Binder V, Finkel Y, Cortot A, Modigliani R, Laurent-Puig P, Gower-Rousseau C, Macry J, Colombel JF, Sahbatou M, Thomas G: Association of NOD2 leucine-rich repeat variants with susceptibility to Crohn's disease. Nature 2001, 411:599-603.

31. Barrett JC, Hansoul S, Nicolae DL, Cho JH, Duerr RH, Rioux JD, Brant SR, Silverberg MS, Taylor KD, Barmada MM, Bitton A, Dassopoulos T, Datta LW, Green T, Griffiths AM, Kistner EO, Murtha MT, Regueiro MD, Rotter Jl, Schumm LP, Steinhart AH, Targan SR, Xavier RJ; NIDDK IBD Genetics Consortium, Libioulle C, Sandor C, Lathrop M, Belaiche J, Dewit O, Gut I, et al.: Genomewide association defines more than 30 distinct susceptibility loci for Crohn's disease. Nat Genet 2008, 40:955-962.

32. McGovern DP, Gardet A, Torkvist L, Goyette P, Essers J, Taylor KD, Neale BM, Ong RT, Lagace C, Li C, Green T, Stevens CR, Beauchamp C, Fleshner PR, Carlson M, D'Amato M, Halfvarson J, Hibberd ML, Lördal M, Padyukov L, Andriulli A, Colombo E, Latiano A, Palmieri O, Bernard EJ, Deslandres C, Hommes DW, de Jong DJ, Stokkers PC, Weersma RK, et al: Genome-wide association identifies multiple ulcerative colitis susceptibility loci. Nat Genet 2010, 42:332-337.

33. Dorhoi A, Desel C, Yeremeev V, Pradl L, Brinkmann V, Mollenkopf HJ, Hanke K, Gross O, Ruland J, Kaufmann SH: The adaptor molecule CARD9 is essential for tuberculosis control. J Exp Med, 207:777-792.

34. Yamazaki K, McGovern D, Ragoussis J, Paolucci M, Butler H, Jewell D, Cardon L, Takazoe M, Tanaka T, Ichimori T, Saito S, Sekine A, lida A, Takahashi A, Tsunoda T, Lathrop M, Nakamura Y: Single nucleotide polymorphisms in TNFSF15 confer susceptibility to Crohn's disease. Hum Mol Genet 2005, 14:3499-3506.

35. Khor CC, Chapman SJ, Vannberg FO, Dunne A, Murphy C, Ling EY, Frodsham AJ, Walley AJ, Kyrieleis O, Khan A, Aucan C, Segal S, Moore CE, Knox K, Campbell SJ, Lienhardt C, Scott A, Aaby P, Sow OY, Grignani RT, Sillah J, Sirugo G, Peshu N, Williams TN, Maitland K, Davies RJ, Kwiatkowski DP, Day NP, Yala D, Crook DW, et al: A Mal functional variant is associated with protection against invasive pneumococcal disease, bacteremia, malaria and tuberculosis. Nat Genet 2007, 39:523-528

36. Ramasawmy R, Cunha-Neto E, Fae KC, Borba SC, Teixeira PC, Ferreira SC, Goldberg AC, lanni B, Mady C, Kalil J: Heterozygosity for the S180L variant of MAL/TIRAP, a gene expressing an adaptor protein in the Toll-like receptor pathway, is associated with lower risk of developing chronic Chagas cardiomyopathy. J Infect Dis 2009, 199:1838-1845.

37. Castiblanco J, Varela DC, Castano-Rodriguez N, Rojas-Villarraga A, Hincapie ME, Anaya JM: TIRAP (MAL) S180L polymorphism is a common protective factor against developing tuberculosis and systemic lupus erythematosus. Infect Genet Evol 2008, 8:541-544.

38. Nejentsev S, Thye T, Szeszko JS, Stevens H, Balabanova Y, Chinbuah AM, Hibberd M, van de Vosse E, Alisjahbana B, van Crevel R, Ottenhoff TH, Png E, Drobniewski F, Todd JA, Seielstad M, Horstmann RD: Analysis of association of the TIRAP (MAL) S180L variant and tuberculosis in three populations. Nat Genet 2008, 40:261-262; author reply 262-263.

doi:10.1186/gm173

Cite this article as: Khor CC, Hibberd ML: Shared pathways to infectious disease susceptibility? Genome Medicine 2010, 2:52. 